\title{
Combining Rainwater Harvesting and Grass Reseeding to Revegetate Denuded African Semi-arid Landscapes
}

\author{
Kevin Z. Mganga ${ }^{1,2}$ (D) $\cdot$ Luwieke Bosma $^{3} \cdot$ Kevin O. Amollo $^{1} \cdot$ Theophilus Kioko $^{3} \cdot$ Nancy Kadenyi $^{3}$ (1) \\ Aphaxard J. N. Ndathi ${ }^{1}$. Stephen M. Wambua ${ }^{1}$ - Eric M. Kaindi ${ }^{1}$. Gilbert K. Musyoki ${ }^{1}$ - Nashon K. R. Musimba ${ }^{1}$. \\ Frank van Steenbergen ${ }^{3}$
}

Received: 14 October 2021 / Revised: 19 November 2021 / Accepted: 19 November 2021 / Published online: 3 December 2021

(c) The Author(s) 2021

\begin{abstract}
In African drylands, perennial grasses preferred by grazing livestock are disappearing at an alarming rate. This has led to recurrent livestock feed shortages threatening pastoralist's livelihoods. Combining native grass reseeding and rainwater harvesting offers a viable and innovative solution to reverse this trend. However, studies to determine how biomass yields are affected by soil moisture availability attributed to in situ rainwater harvesting in African drylands are limited. We investigated how biomass yields of three grasses native to Africa, i.e., Enteropogon macrostachyus (Bush rye grass), Cenchrus ciliaris (African foxtail grass), and Eragrostis superba (Maasai love grass), are affected by soil moisture content in a typical semi-arid landscape. Rainwater harvesting structures included trenches, micro-catchments and furrows. Additionally, rain runoff was diverted from an adjacent road used as a catchment area. Soil moisture was measured between November 2018 and August 2019 using PlantCare Mini-Logger sensors installed at 40 and $50 \mathrm{~cm}$ depths and 0, 1, 5 and $15 \mathrm{~m}$ away from the trench. Quadrat method was used to determine biomass yields in August 2019. Peaks in soil moisture were observed after rainfall events. Soil moisture content gradually decreased after the rainy season, but was higher closer to the trench. This is attributed to the prolonged rainwater retention in the trenches. Biomass yields were in the order Eragrostis superba $>$ Cenchrus ciliaris $>$ Enteropogon macrostachyus. Biomass production was higher near the trenches for all the studied species. Sensitivity to soil moisture demonstrated by the magnitude to yield reduction during the growing season was in the order Eragrostis superba $>$ Cenchrus ciliaris $>$ Enteropogon macrostachyus. These results suggest that Eragrostis superba is more sensitive to drought stress than Enteropogon macrostachyus that is adapted to a wide range of soil moisture conditions. We demonstrated that in situ rainwater harvesting structures enhanced soil moisture availability and displayed great potential for revegetating denuded natural rangelands in semi-arid African landscapes. Thus, combining rainwater harvesting and reseeding techniques can produce measurable improvements in pastoral livelihoods and should be incorporated in dryland development policies
\end{abstract}

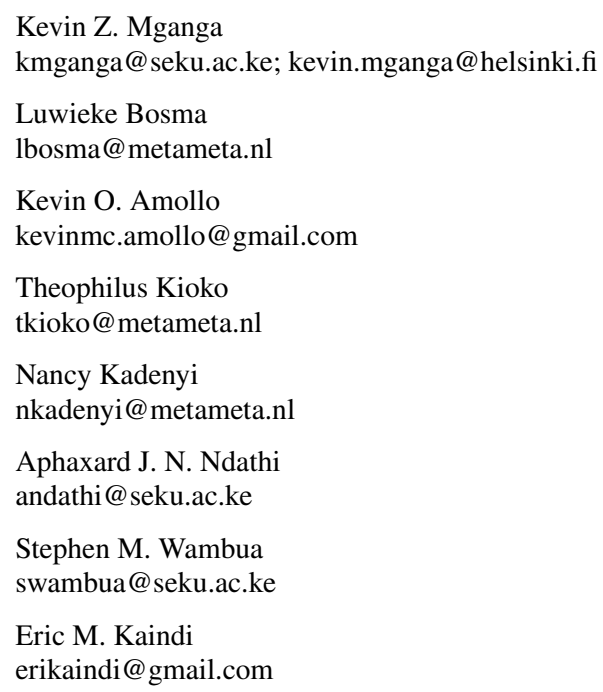

Gilbert K. Musyoki gmusyoki@seku.ac.ke

Nashon K. R. Musimba nkrmusimba@gmail.com

Frank van Steenbergen fvansteenbergen@metameta.nl

Department of Agricultural Sciences, South Eastern Kenya University, P.O. Box 170-90200, Kitui, Kenya

2 Department of Agricultural Sciences, University of Helsinki, Koetilantie 5, 00790 Helsinki, Finland

3 MetaMeta Research, Nude 54 D, 6702 DN Wageningen, The Netherlands 
in the region. Ultimately, incorporating such innovative strategies can strengthen the effectiveness of ecological restoration in African drylands to meet the objectives of the UN Decade on Ecosystem Restoration and achieving the UN Sustainable Development Goals.

\section{Graphical abstract}

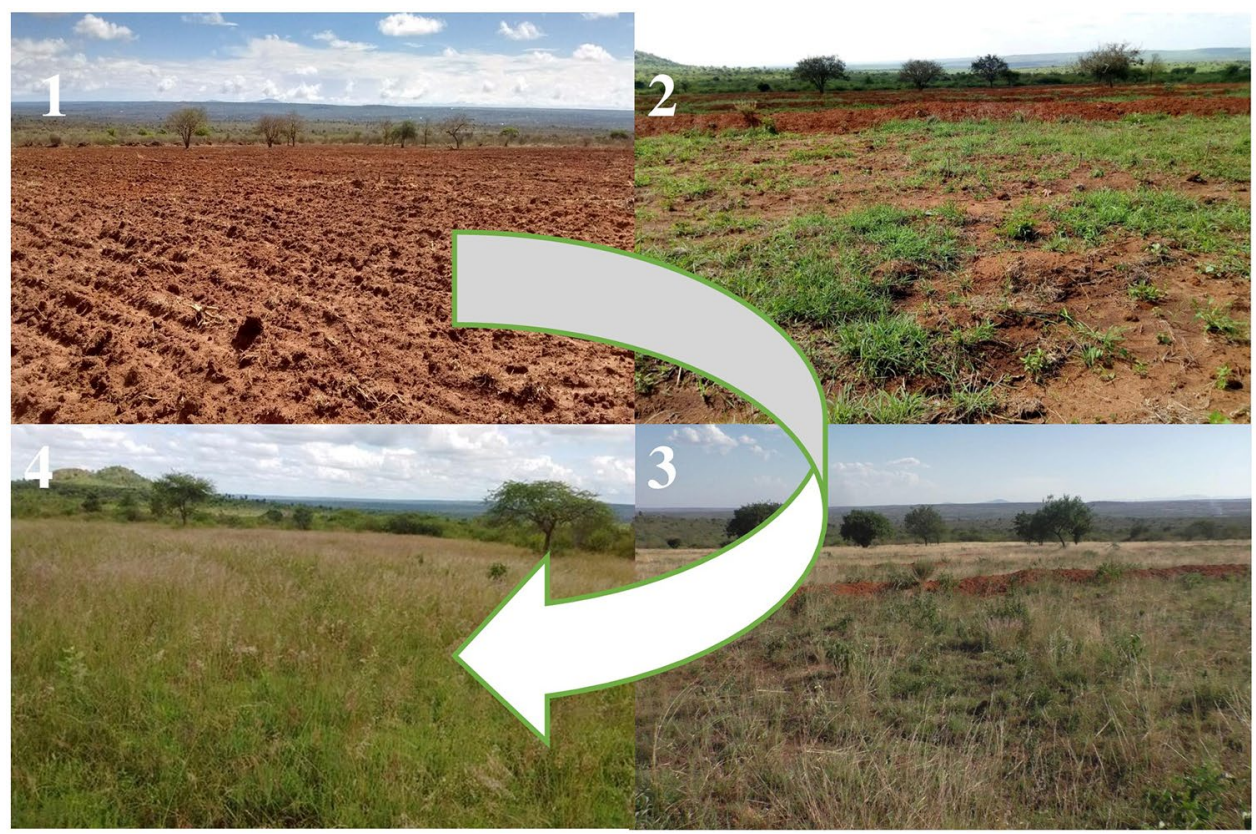

Keywords Biomass $\cdot$ Drylands $\cdot$ Grasses $\cdot$ Perennials $\cdot$ Rangeland $\cdot$ Runoff $\cdot$ Reseeding $\cdot$ Soil moisture $\cdot$ Sustainability

\section{Introduction}

Global drylands account for $\sim 41 \%$ of the earth's surface and are host to approximately 2 billion people whose livelihoods mainly depend on the services provided by these ecosystems (Berdugo et al. 2021). More than 1 billion people from the developing world depend on dryland natural resources to sustain their livelihoods (Ryan and Elsner 2016). In Africa, dryland ecosystems are home to over 100 million pastoralists, whose livelihoods are derived mainly from subsistence livestock production characterized by mobility in search of forage and water resources (King et al. 2018). In Kenya, arid and semi-arid drylands cover approximately $90 \%$ of the country's landmass and hosts approximately $30 \%$ and $70 \%$ of the human and livestock populations, respectively (Amwata et al. 2016).

Native grass pastures provide the main source for forage for the free-ranging livestock. Dryland environments in Kenya receive very low and erratic bimodal rainfall that is highly variable. On average, annual rainfall ranges from 150 to $450 \mathrm{~mm}$ and 500 to $850 \mathrm{~mm}$, in the arid and semi-arid lands, respectively (Huang et al. 2016). However, rainfall in the Kenyan drylands is highly variable in space, and time with some years characterized by above and below average annual rainfall. Subsequently, interannual rainfall in these environments can vary from 50 to $100 \%$ in arid lands and 20 to $30 \%$ in the semi-arid lands (Mumo et al. 2019). This erratic nature and low rainfall regimes and recurrent droughts have partly contributed to the gradual depletion of native perennial forage resources for livestock in these drylands. Current and projected climate trends across most of African drylands show increasing drought frequency and rainfall variability (Sheffield and Wood 2008). This worsens vegetation degradation and escalates environmental sensitivity to drought, leading to ecological and social vulnerability among pastoralists (Bardgett et al. 2021; King et al. 2018).

In addition, an increased pressure on the arid and semiarid drylands in Kenya in the last 3 decades has contributed to severe degradation. Shrinkage of the pastoral-production livestock feed resource base has confined pastoralists to the less productive grazing lands. This has resulted in further depletion and fast disappearance of preferred native grasses forage resources threatening the sustainability of land production systems and livelihoods of pastoralist communities (Mganga et al. 2015). Drylands are particularly vulnerable, because the soils have a relatively poor soil structure because 
of low levels of organic matter. Decline in primary productivity, loss of biodiversity and accelerated rate of soil erosion are degradation's evidence in these environments (Mureithi et al. 2014). Natural grazing pastures and forage resources have reduced in quantity and quality, exposing the pastoral livestock to perennial feed scarcity, especially during the long lean dry seasons. Considering that livestock are critical to rural household incomes, livelihoods, nutrition and food security and resilience in African drylands, there is need to explore innovations which can contribute to improved establishment of grass pastures in their native environment.

Livestock destocking, rangeland bush management and controlled grazing patterns have been used to improve the quantity and quality of native pastures and replenish depleted rangelands (Angassa 2014). Other strategies such as tilling, ripping and seeding are rare in pastoral drylands. This is mainly because of their high capital requirements (Mureithi et al. 2016; van den Berg and Kellner 2005). A combination of in situ rainwater harvesting and revegetation through minimal soil disturbance and native grass reseeding has the potential to restore depleted grazing pastures and improve their potential for livestock production in dryland landscapes. Such innovative strategies have a great potential to strengthen the effectiveness of ecological restoration in African drylands to meet the aspirations of the UN Decade on Ecosystem Restoration and attaining the UN Sustainable Development Goals.

In situ rainwater harvesting (e.g., trenches, micro-catchments, furrows) is one of the promising practices to support sustainable development in African drylands facing climate change impacts (Vohland and Barry 2009). This is because such structures enhance water infiltration thus providing an excellent opportunity to stabilize dryland landscapes, through restoration of degraded natural grazing lands, making them more productive and resilient (Lal 2001). Additionally, marginal water sources, e.g., road and land runoffs, which are normally lost through erosion processes, can also be harvested and used more efficiently. Minimal soil disturbance through the creation of shallow micro-catchments traps rainwater and surface runoff, and thus promotes seed germination and subsequent establishment and development of the seedlings (Visser et al. 2007).

Use of native perennial grass seeds for reseeding depleted arid and semi-arid rangelands is advantageous because of their better survival and growth. They also reduce the risk of restoration failure attributed to poor adaptation to prevailing environmental conditions, restricting local gene pools 'pollution' and outbreeding depression (Mganga et al. 2021; Broadhurst et al. 2008). Moreover, perennial grasses native to African drylands are prolific seeders and efficient in seed dispersal, and thus have a great potential of replenishing depleted seed banks (Marshall et al. 2012). Therefore, in this study, we reseeded a typical semi-arid landscape with three grass species native to African drylands, i.e., Eragrostis superba (Maasai love grass), Cenchrus ciliaris (African foxtail/Buffel grass) and Enteropogon macrostachyus (Bush rye grass). Selection criteria of these three grasses was not only based on their evolved adaptive mechanisms for survival in African drylands, but also their multipurpose uses among pastoral communities, e.g., livestock feed, source of income (sale of seed and hay), thatching material and role in soil conservation (Mganga et al. 2015; Mureithi et al. 2016). Some general characteristics of the selected grasses are shown in Table 1. Trenches were excavated to harvest rainwater and store surface runoff diverted from a road adjacent to the site. Additionally, minimal soil disturbance was achieved by creating shallow ox-driven plough micro-catchments (around $15 \mathrm{~cm}$ depth) that also supplemented rainwater harvesting. These in situ rainwater harvesting structures were set up to assess their potential contribution in enhancing soil moisture content and their subsequent contribution to sustainable native pasture production.
Table 1 Morphometric characteristics of selected perennial grasses used for reseeding Kenyan dryland environments

\begin{tabular}{|c|c|c|c|c|}
\hline \multirow[t]{2}{*}{ Plant trait } & \multirow[t]{2}{*}{ Units } & \multicolumn{3}{|c|}{$\begin{array}{l}\text { Selected characteristics of perennial grasses native to African } \\
\text { drylands }\end{array}$} \\
\hline & & Cenchrus ciliaris & $\begin{array}{l}\text { Enteropogon } \\
\text { macrostachyus }\end{array}$ & Eragrostis superba \\
\hline Distribution & m a.s.1 & $0-2000$ & $300-1600$ & $0-2000$ \\
\hline Leaf blade & $\begin{array}{l}\text { Length, } \mathrm{cm} \\
\text { Width, mm }\end{array}$ & $\begin{array}{l}15-30 \\
3-8\end{array}$ & $\begin{array}{l}10-60 \\
2-10\end{array}$ & $\begin{array}{l}\text { Up to } 40 \\
3-12\end{array}$ \\
\hline Stem thickness & Width, mm & $1-2$ & $1-2$ & $2-3$ \\
\hline Height & $\mathrm{cm}$ & $20-150$ & $30-100$ & $20-120$ \\
\hline Rooting depth & $\mathrm{cm}$ & Up to 240 & Up to 220 & Up to 220 \\
\hline Inflorescence type & & Panicle & Spike & Panicle \\
\hline Inflorescence length & $\mathrm{cm}$ & $2-14$ & $8-20$ & $10-30$ \\
\hline Optimal rainfall & $\mathrm{mm}$ & $300-750$ & $550-800$ & $500-900$ \\
\hline Crude protein & $\%$ & Up to 10 & $9-12$ & Up to 15 \\
\hline
\end{tabular}


Thus, the broad objective for this study was to determine the potential of in situ rainwater to prolong soil moisture availability and thus enhance sustainable native pasture biomass production in a typical semi-arid landscape in Africa. Specifically, we aimed at establishing: (1) how in situ rainwater harvesting prolongs soil moisture availability and (2) how the soil moisture availability influences biomass yields of three grass forages native to African drylands.

\section{Materials and Methods}

\subsection{Study Area}

This study was conducted in semi-arid landscape in Kitui County, southeastern Kenya (Fig. 1) (GPS coordinates latitude $\mathrm{S} 1^{\circ} 19^{\prime} 1.02317^{\prime \prime}$ and longitude E $37^{\circ} 45^{\prime} 26.75293^{\prime \prime}$ ). Akamba agropastoralists are the main inhabitants in the area. The main land-use system is a mix of local livestock breeds notably small East African shorthorn zebu, Red Maasai sheep and small East African goats and droughttolerant cereals and pulses like millet, sorghum, pigeon peas, cowpeas and mung bean (Mganga et al. 2015), and characterizes crop-livestock production. Rainfall pattern is bimodal, with the long rains (LR) in March-May and short rains (SR) in October-December. Intense LR have a rain peak in April, while the less intense SR have a rain peak in November. Total annual rainfall averages range between 300 and $800 \mathrm{~mm}$ and the monthly temperatures range between 14 and $34{ }^{\circ} \mathrm{C}$, with a mean of $24^{\circ} \mathrm{C}$ (Schmitt et al.
2019). Soils are generally shallow, low in organic matter and available nutrients, especially nitrogen and phosphorus. Some of the soil classes in Kitui County include Vertisols, Cambisols, Luvisols, Ferralsols, Arenosols, Gleysols and Acrisols (in the study site). Soil surface sealing and low infiltration rates expose the soils to erosion, because heavy rains come early in the growing season, when the land is bare after the dry season. On average, the soils are characterized by the following physicochemical parameters: $\mathrm{pH}$ (6.4), total organic $\mathrm{C}\left(9.7 \mathrm{~g} \mathrm{~kg}^{-1}\right)$, total $\mathrm{N}\left(1.2 \mathrm{~g} \mathrm{~kg}^{-1}\right)$, total available $\mathrm{N}\left(11.7 \mathrm{mg} \mathrm{kg}^{-1}\right)$, available $\mathrm{P}\left(73 \mathrm{mg} \mathrm{kg}^{-1}\right), \mathrm{K}$ $\left(1.1 \mathrm{cmol} \mathrm{kg}^{-1}\right), \mathrm{Na}\left(0.4 \mathrm{cmol} \mathrm{kg}^{-1}\right)$, and CEC $(10.1 \mathrm{cmol}$ $\mathrm{kg}^{-1}$ ) (Yageta et al. 2019). Common tree and shrub species include Lannea triphylla (Hochst. ex A. Rich.) Engl., Commiphora africana (A. Rich.) Endl., Acacia mellifera (M. Vahl) Seigler \& Ebinger and Acacia senegal (L.) Britton. Grasses such as C. roxburghiana, E. superba, C. ciliaris, E. macrostachyus and Rhynchelytrum repens (Willd.) Zizka dominated the herbaceous layer.

\subsection{Field Site Layout and Land Preparations}

The general study site (area of 2.79 ha and a slope of 5\%) layout is shown in Fig. 2a. Perimeter of the site was approximately $0.68 \mathrm{~km}$ and the length from highest to lowest point was $250 \mathrm{~m}$. The barren land was ploughed across the slope with oxen-plough to create micro-catchments. Thereafter, the trenches were dug to collect runoff water diverted from the adjacent road. Some general soil characteristics of the
Fig. 1 Map of study location, Kitui County, southeastern Kenya

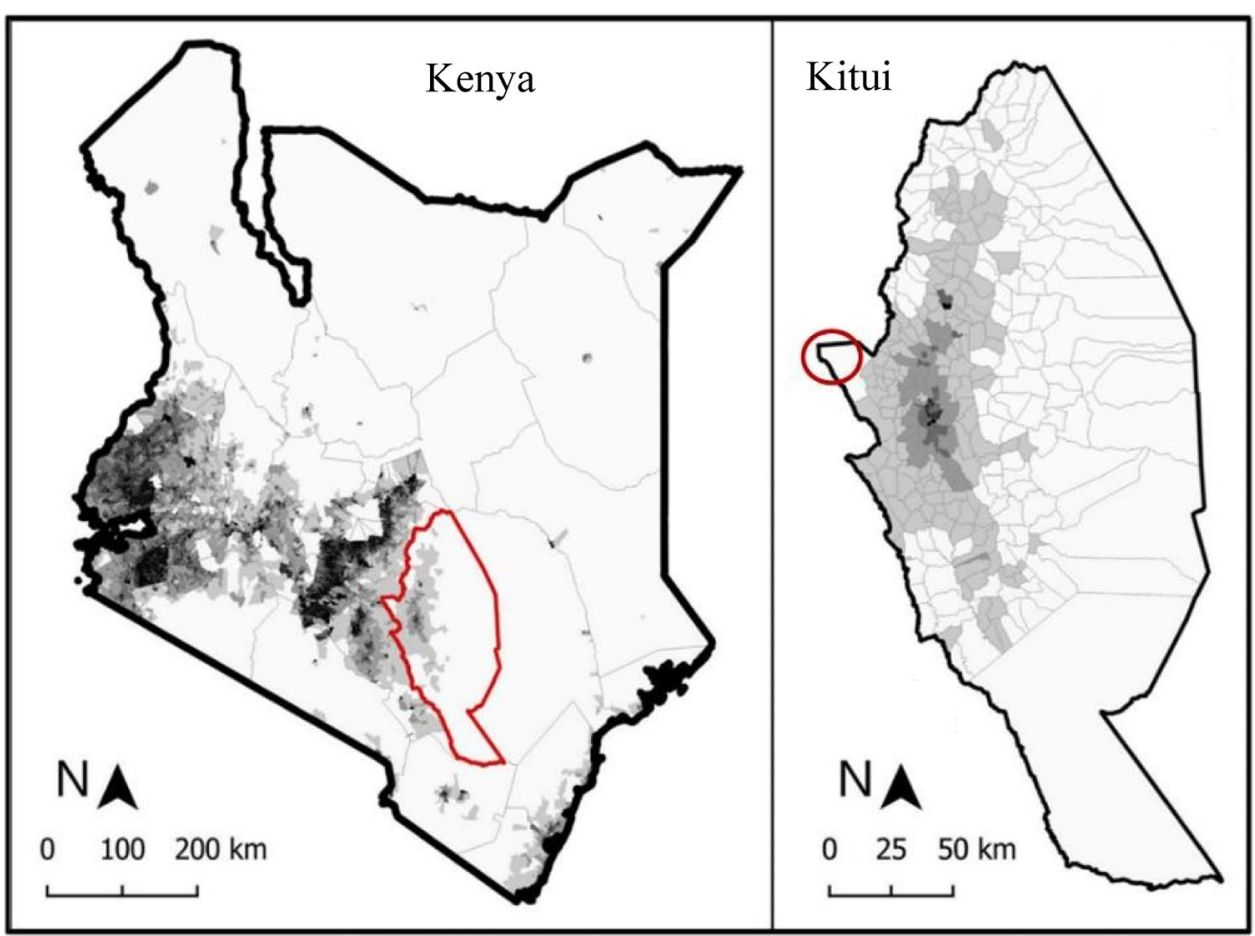


(a)

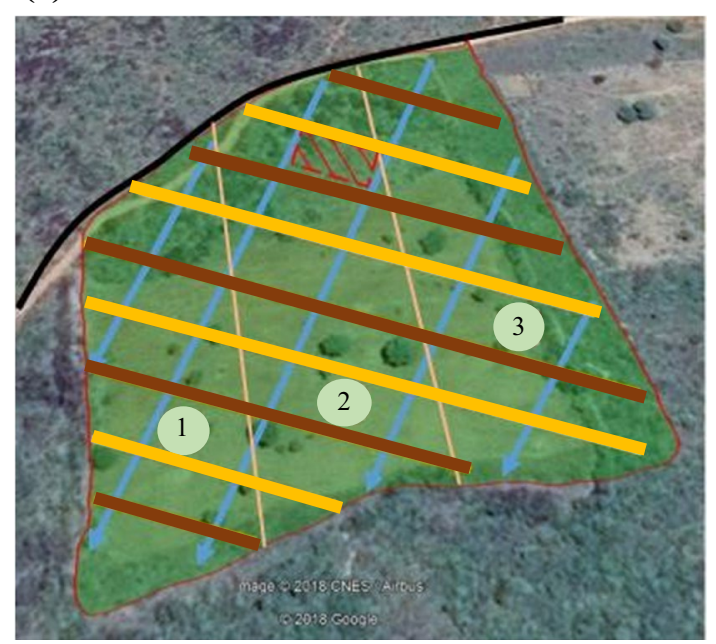

Deep trench $(0.9 \mathrm{~m}$ wide $\mathrm{x} 0.9 \mathrm{~m}$ deep $)$

Shallow trench $(0.9 \mathrm{~m}$ wide $\mathrm{x} 0.6 \mathrm{~m}$ deep $)$

Direction of slope

הIth (b)

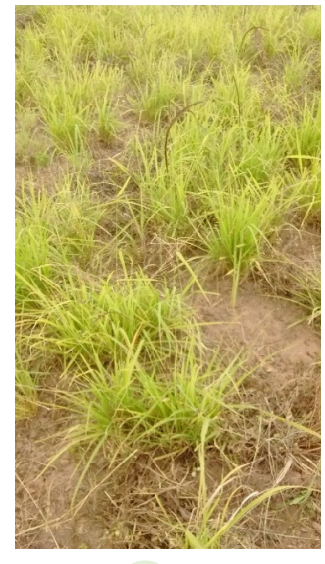

1

Enteropogon macrostachyus

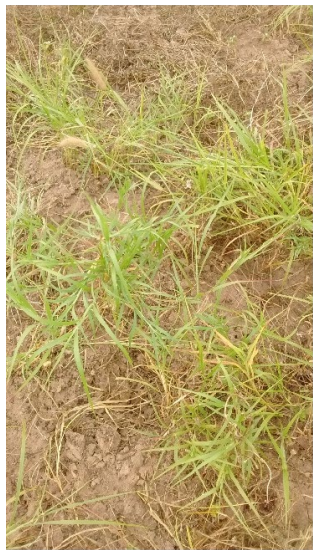

2

Cenchrus ciliaris

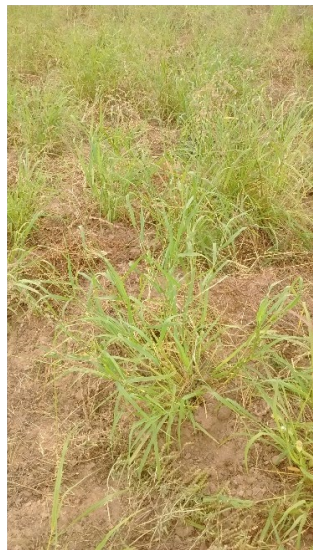

3

Eragrostis superba

Fig. 2 a Layout of the experimental blocks and in situ rainwater harvesting structures and $\mathbf{b}$ photo plates of the grasses established. (Photo credit: Kevin Z. Mganga)

site were: total nitrogen $0.07 \%$, total carbon $0.8 \%, \mathrm{C}: \mathrm{N}$ ratio of 11 , total phosphorus $165 \mathrm{mg} \mathrm{kg}^{-1}$, organic carbon $1.9 \%$, humus $3.4 \%$, clay texture-sand $7.96 \%$, silt $19.65 \%$ and clay $72.39 \%$.

\subsection{Sowing and Plant Morphometric Characteristics' Measurements}

Recommended and desired seeding rate $\left(5 \mathrm{~kg} \mathrm{ha}^{-1}\right)$ for grasses native to Kenyan drylands (Fig. 2b) was used for sowing the seeds, prior to the onset of the short rains (November, 2018). Here, we also adhered to the home site advantage principal using native seeds to conserve a readily adapted potential for reseeded populations to evolve (Visser and Reheul 2001). Biomass production was measured nine (9) months after sowing to estimate accumulated yields over two growing seasons. Plant biomass measurements were taken in three (3) parallel transects, i.e., T1, T2 and T3 representing 1,5 and $15 \mathrm{~m}$ after the trenches, in each species block (Fig. 2a) to estimate the total yields in two growing seasons. Destructive sampling was used to determine aboveground biomass production. Briefly, $0.25 \mathrm{~m}^{-2}$ quadrats were used and clipped to a stubble height of $2 \mathrm{~cm}$. Thereafter, harvested aboveground biomass was placed in paper bags and oven dried at $60{ }^{\circ} \mathrm{C}$ for $24 \mathrm{~h}$ to determine dry matter (DM) yield. Sensitivity $(S)$ to drought of biomass production (Ghannoum et al. 2002) was calculated as the ratio of biomass produced under water-stress ( $15 \mathrm{~m}$ from trench) to well-watered (1 $\mathrm{m}$ from trench) soil moisture conditions.

\subsection{Soil Moisture Measurements}

Soil moisture content was determined using mini-logger sensors (PlantCare Mini-Logger) at 40-50 cm depth. Six (6) sensors were used. Briefly, sensors 1-4 were placed at a $40 \mathrm{~cm}$ depth, while sensors $5-6$ were placed at $50 \mathrm{~cm}$ depth. Thus, Sensor 1, inserted $40 \mathrm{~cm}$ deep inside the trench (depth of $60 \mathrm{~cm}$ ), was at $100 \mathrm{~cm}$ depth. Sensors 1-4 $(40 \mathrm{~cm}$ depth) were installed in early November 2018, while sensors 5-6 (50 cm depth) in early April 2019. Data collected from the sensors installed in the field were analysed with PlantCare software. The layout of the positioning and depth of the mini-logger sensors is shown in Fig. 3a. Data were collected between November 2018 and August 2019. This was aimed at capturing the soil moisture trend during the SR (October-December) and LR (March-May) and the dry seasons in-between the two rainy season (Fig. 3b).

\subsection{Statistical Data Analysis}

Statistical analyses were performed using STATISTICA 10.0 (StatSoft Inc). Factorial analysis of variance (ANOVA) was used to determine whether there are any statistically significant differences in aboveground biomass yields as influenced 
(a)

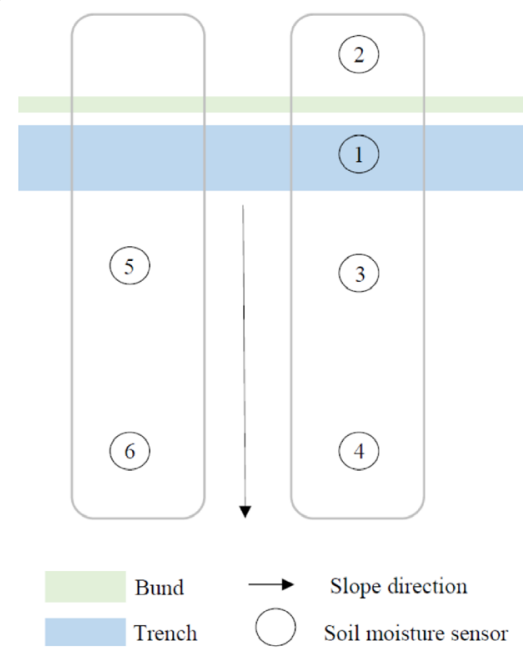

(b)

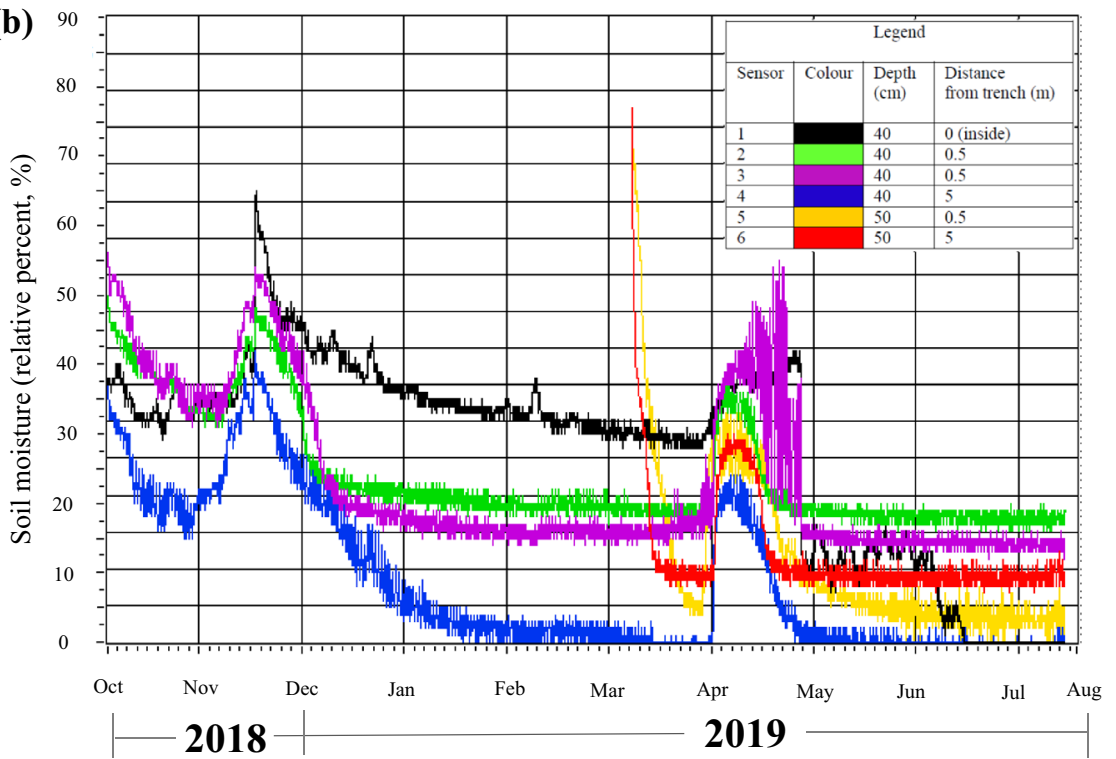

Fig. 3 a Positioning and depth of the mini-logger sensors and $\mathbf{b}$ soil moisture content (relative \%) at different depths and distance from trench. Numbers 1-6 represent soil moisture sensors placed at different distances from the trench and soil depths

by distance from in situ rainwater harvesting structures, i.e., trenches. Tukey's HSD post hoc test was used to separate significant differences, at $\alpha=0.05$.

\section{Results}

\subsection{Climate Data: Rainfall and Temperature}

Climate data, i.e., rainfall and temperature, were obtained from South Eastern Kenya University (SEKU) Meteorological Station, Kitui Meteorological Department and Kenya Meteorological Department. Total rainfall recorded during the study period, i.e., October 2018-August 2019, was $863 \mathrm{~mm}$. Short rains of October-December, 2018 and long rains of March-May, 2019 recorded total amounts of 260 and $386 \mathrm{~mm}$, respectively (Fig. 4). In total, there were 200 rainy days with 69 and 57 rainy days for the short and long rains, respectively. During the study period, April 2019 (244 mm) and August 2019 (13 mm) were the wettest and driest months. Average temperature range was between 19 and $24{ }^{\circ} \mathrm{C}$. Maximum and minimum temperature ranges were between 22 and $28^{\circ} \mathrm{C}$ and 15 and $19^{\circ} \mathrm{C}$, respectively. Highest temperature was recorded in March 2019, prior to the long rains peak in April (Fig. 4).
Fig. 4 Rainy days and monthly rainfall $(\mathrm{mm})$ and average monthly temperatures $\left({ }^{\circ} \mathrm{C}\right)$ during the study period. Source: South Eastern Kenya University (SEKU) Meteorological Station, Kitui Meteorological Department and Kenya Meteorological Department
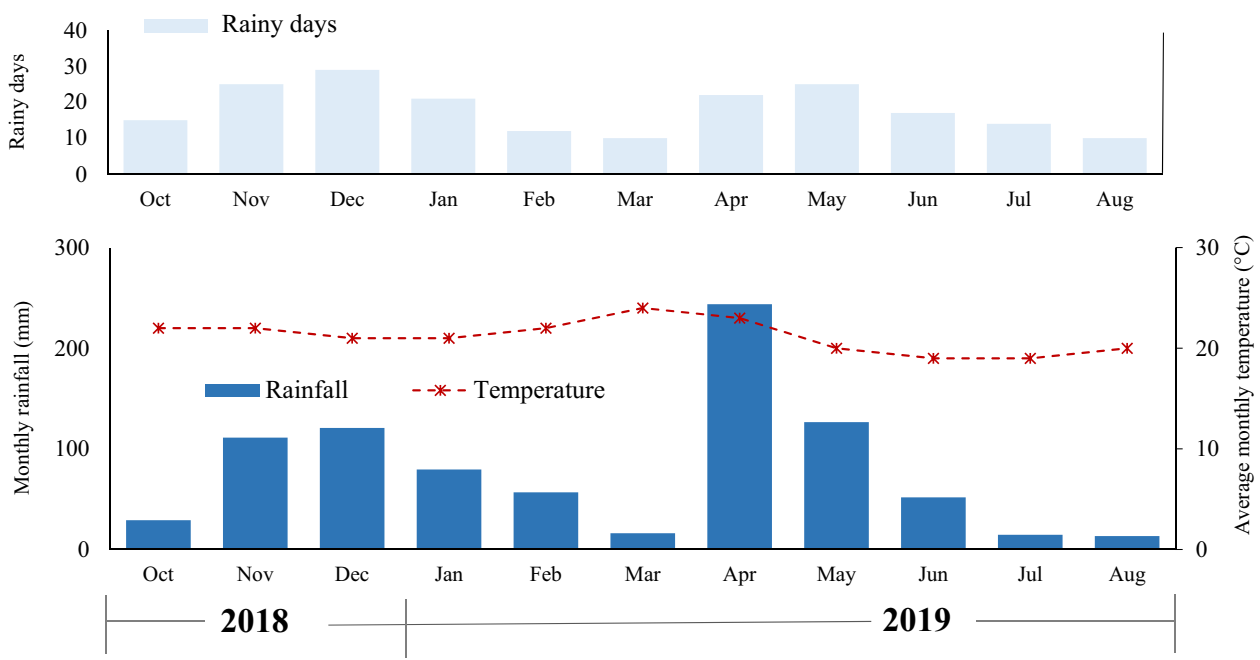


\subsection{Soil Moisture Data}

Soil moisture data as a relative percent of soil moisture content are shown in Fig. 3b. Sensor 1 (black) placed at $100 \mathrm{~cm}$ depth below the trench floor displayed two peaks at the onset of the short and long rains, and had higher soil moisture over a 7-month period between November (2018) and April (2019), compared to the other sensors. During this period, soil moisture as a relative percent of soil moisture content dropped from 65 to $30 \%$, increasing to around $42 \%$ in May 2019 because of the long rains.

Sensors 2 and 3 (green and purple, respectively), placed $0.5 \mathrm{~m}$ from the trench (lower and upper side of the $5 \%$ slope), at a depth of $40 \mathrm{~cm}$, displayed a similar pattern and trend in soil moisture. Over a period of 7 months (i.e. November 2018 to April 2019), soil moisture, as a relative percent of soil moisture content, dropped from the range $50-55 \%$ to $15-20 \%$, and increased to $38-55 \%$ in May, 2019 , after the onset of the long rains. The soil moisture gradually dropped back to 15-20\% into the dry season.

Sensor 4 (blue) at $40 \mathrm{~cm}$ depth, $5 \mathrm{~m}$ from the trench had the lowest soil moisture throughout the entire study period. It also displayed two distinct peaks in early December 2018 (40\%) and late April 2019 (25\%), conceding with the period after the short and long rain peaks, respectively. As the dry seasons progressed, the moisture dropped to very low levels of less than $5 \%$.

Sensors 5 (yellow, $0.5 \mathrm{~m}$ from trench, $50 \mathrm{~cm}$ depth) and 6 (red, $5 \mathrm{~m}$ from trench, $50 \mathrm{~cm}$ depth) were installed later in early April 2019. Peak readings in early April 2019 were because of the mini-logger installation process that involves placing the sensors in water for a few minutes, before inserting them into the soil. Thereafter, the sensors measured soil moisture, represented by peaks of relative percent moisture of around $30 \%$ in late April 2019. Thereafter, the readings of sensors 5 and 6 gradually dropped and remained stable at 5 and $10 \%$, respectively, into the dry season.

\subsection{Aboveground Biomass Yields}

Overall, E. superba had significantly higher biomass yields $(P<0.05)$ at 1,5 and $15 \mathrm{~m}$ distance from the trench (Fig. 5). Cenchrus ciliaris and E. macrostachyus were ranked second and third, respectively. Biomass yields were generally higher at $1 \mathrm{~m}$ than $15 \mathrm{~m}$ distance from the trench, in three grass species. Reduction in biomass yield was 55,50 and $28 \%$ for E. superba, C. ciliaris and E. macrostachyus, respectively. Additionally, the water-stressed (15 m from trench)/wellwatered ( $1 \mathrm{~m}$ from trench) ratios of the three grasses were $0.72,0.53$ and 0.44 for E. macrostachyus, C. ciliaris and $E$. superba, respectively.

\section{Discussion}

\subsection{Rainfall Pattern and Plant Establishment}

The two rainfall peaks in October-December 2018 (short rains, SR) and April-May 2019 (long rains, LR) during the study period (Fig. 4) illustrated the bimodal rainfall pattern in southeastern Kenya (Schmitt et al. 2019; Yageta et al. 2019). Total rainfall during the SR $(260 \mathrm{~mm})$ and LR $(386 \mathrm{~mm})$ received and average monthly temperature range of between 19 and $24{ }^{\circ} \mathrm{C}$ are representative of semi-arid landscapes in Africa. Climate in semi-arid Kitui is normally hot most of the year with monthly average temperatures ranging between 14 and $34{ }^{\circ} \mathrm{C}$ and average annual rainfall ranges between 250 and $1050 \mathrm{~mm}$ (Yageta et al. 2019). In the arid and semi-arid Kenyan drylands, the October-December $\mathrm{SR}$ is the important and main season for crop production (Mumo et al. 2019; Eriksen and Lind 2009).
Fig. 5 Biomass yields $\left(\mathrm{kg} \mathrm{ha}^{-1}\right)$ and sensitivity to drought of the three grass species. Error bars represent standard error of means $( \pm S E)$. Bars with different letters indicate statistically significant differences at $\alpha=0.05, n=27$

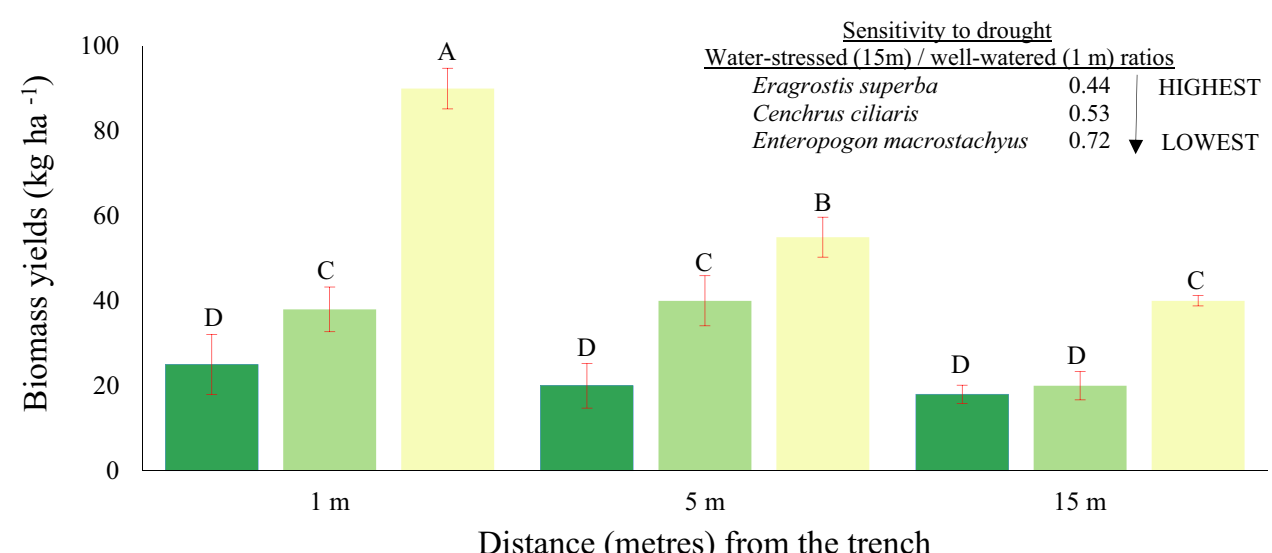

Enteropogon macrostachyus $\quad$ Cenchrus ciliaris Eragrostis superba 
The rainfall pattern and reliability informed the timing of seed sowing, i.e., before the onset of the SR in 2018 (dry planting). Sowing of grass seeds native to African drylands prior to the SR improves the chances of the emerging seedlings to survive and establish. This is because the emerging grass seedlings will: (1) take advantage of more reliable SR for fast growth, (2) endure a much shorter dry spell (January-February), and (3) utilize the March-May LR subsequent establishment. Dry planting, a traditional agronomic practice in dryland environments, aims at limiting the period seedlings are exposed to water-deficit conditions. The goal is to ensure that once the seeds are planted, soil moisture conditions are sufficient to trigger germination and subsequent establishment. This strategy contributed to the successful establishment and survival of the selected grass species. Other studies (e.g., Shackelford et al. 2021; Mganga et al. 2015) have also demonstrated that timing is strongly associated with successful seedling establishment in dryland environments. Poor physical properties are exacerbated by low organic matter contribute to low water-holding capacity of dryland soils, limiting its water storage capacity (Lal 2001). Thus, manipulating the soil by creating in situ rainwater harvesting structures has great potential to help overcome dry spells in drylands by reducing surface runoff, enhancing infiltration and prolong water availability for plant growth (Vohland and Barry 2009).

\subsection{Rainwater Harvesting and Soil Moisture}

There was a sharp increase (peak) in soil water content after each rainfall event, followed by a gradual decrease (valleys) over a period of 5 months, an indication of the soil drying (Fig. 3b). However, soil moisture was least depleted inside the trench (sensor 1, Fig. 3b). These results suggest that in situ rainwater harvesting structures, e.g., trenches, have a great potential to prolong water availability. In situ rainwater structures are thus beneficial for pasture establishment in African drylands, because enhanced water availability promotes faster growth and higher biomass production that can be harvested several times during the growing season. Higher soil moisture content in the excavated trenches is attributed to a greater water retention and reduction in runoff velocity. Trenches act as speed breakers to the runoff, thus increasing percolation of harvested water down the soil profile. Furthermore, loss of soil moisture through evaporation may be less in depressions than flat lands; thus, layers remain at relatively higher moisture content in trenches (Lenka et al. 2012). Soil bunds combined with Vetiveria zizanioides grass in short trenches in a grassland enhanced soil moisture up to 55\% in the Upper Blue Nile Basin of Ethiopia (Sultan et al. 2018). Thus, it would be beneficial to establish deep-rooted grass species on both sides of soil bunds to stabilize the soil and reduce sediment deposition in the trenches. Furthermore, the established grasses will also reduce surface runoff along the slope, reducing water velocity and halting particles to flow along with the water. Ultimately, the grasses benefit from enhanced soil moisture availability for subsequent growth and development and simultaneously contribute to water retention. Similar to trenches, comparable in situ rainwater harvesting structures, i.e., dug tied ridges, improved soil water availability in the Tigray drylands, northern Ethiopia (Derib et al. 2009). Soil moisture was least depleted under tied ridges during the growing season commencing 4 weeks after sowing pulses including faba bean (Vicia faba L.), lentil (Lens culinaris Medic.), and field pea (Pisum sativum L.) in high-altitude semi-arid environment, northern Ethiopia (Tesfahunegn and Wortmann 2008).

Trenches exhibit high water-holding capacity and adequate drainage to absorb harvested water with minimal risk of waterlogging. Collected water infiltrates into the root zone and is available to the plants through lateral drainage (Denison and Wotshela 2012). General reduction in soil moisture content with distance away from the newly built trenches/ bunds (sensors 2, 3 and 4, Fig. 3b) suggests that water is stored for a longer time at a shorter distance from the trench. Our results demonstrated that soil moisture retained (52\%) inside the trench was $9 \%$ and $14 \%$ higher than at 0.5 and $5 \mathrm{~m}$, respectively. Likewise, at a comparable slope to our study area, i.e., $5 \%$, average soil moisture content $(17.9 \%)$ recorded at $0.5 \mathrm{~m}$ distance from the trench/bund was 5, 14 and $20 \%$ higher than at 1,2 and $10 \mathrm{~m}$ distance from the bund/trench, respectively, in the rain-fed uplands of the Kokriguda watershed, India (Dass et al. 2011). At the same distance from the trench/bund, soil moisture was higher at $40 \mathrm{~cm}$ (sensors 2 and 4) than $50 \mathrm{~cm}$ (sensors 5 and 6) soil depths, during the rainfall peaks and into the dry season (Fig. 3b). This is probably because of the slow rate of water infiltration to the lower soil horizons, due to poor soil physical properties that lead to hardening and crusting and the clay-textured soils (sand $7.96 \%$, silt $19.65 \%$ and clay $72.39 \%$ ) in the study site. Clay soils are dominated by micropores, and thus have high water and nutrient holding capacity making them less prone to leaching (Tahir and Marschner 2018).

Our results demonstrate that in situ rainwater harvesting structures, e.g., trenches, have a great capacity to collect rainfall and runoff. This allows the collected water to infiltrate into the soil slowly over a longer period, thus enhancing green water. Subsequently, this has a great potential to bridge the gaps of zero rainfall that occur within a rainy season, and to prolong soil moisture availability for a longer time after the rains have ceased. In situ rainwater harvesting is a strategic approach to combat climate vagaries, especially in water-deficit African dryland environments, where landbased production systems, including native pasture production, are largely rain-fed. 


\subsection{Aboveground Biomass Production}

Aboveground biomass yields has been used as an index of successful ecological restoration and indicator of improved productivity of grazing landscapes (Erkossa et al. 2020; Vundla et al. 2020). Our results demonstrate that E. superba was more successful in terms of providing ecosystem services (i.e., biomass production) than C. ciliaris and E. macrostachyus. High biomass production by E. superba (Fig. 5) suggests that it is more suitable for improving productivity, forage availability and increasing the carrying capacity of similar semi-arid landscapes. Higher biomass yields displayed by $E$. superba can be attributed to its inherent superior morphoecological characteristics compared to $E$. macrostachyus and C. ciliaris. Eragrostis superba exhibits taller stems, longer tillers, large stem diameters, high broad leafy biomass and leaf-to-stem ratios (Mganga et al. 2021; Ravhuhali et al. 2019; Koech et al. 2016). These traits enabled $E$. superba to maintain higher vegetative productivity.

Taller species such as E. superba are suitable for sustainable livestock production, because they are more and easily accessible to free-ranging wild and domestic herbivores. This reduces grazing pressure and lowers the potential for land degradation. Livestock prefer grazing on the taller plant species than shorter ones in an open pasture composed of multi-layered forage plants (Santos et al. 2013). Interestingly, pastoral communities in Kenya have also observed a higher preference for $E$. superba compared with $C$. ciliaris and E. macrostachyus among free-ranging grazing livestock in the arid and semi-arid landscapes. This strongly suggests its better stockpiled forage quality (Paredes et al. 2018). Higher biomass yields of E. superba have made it a species of choice among pastoralists (e.g., Pokot and Il Chamus pastoral communities in Kenya) for fattening and improving their body condition score of livestock (Mureithi et al. 2016; Wasonga et al. 2003). Additionally, it is the most preferred species for restoring and rehabilitating denuded pastures. Choice of grass species to combat desertification and ecological restoration among (agro)pastoral communities in east African drylands is largely influenced by their forage value for livestock production (Mganga et al. 2015).

Eragrostis superba maintained a higher vegetative productivity. However, it displayed a significantly higher drop in biomass production with distance away from the trench and lowest water-stressed/well-watered biomass production ratio compared to E. macrostachyus and $C$. ciliaris. This drop in yield is directly linked to changes in soil moisture conditions as influenced by the in situ rainwater harvesting structures, notably, trenches. Perennial grasses native to African drylands have shown a decline in biomass production under water-deficit conditions (Koech et al. 2016; Ghannoum et al. 2002). This clearly shows that in dryland regions of the world, plant growth is strongly limited by scarce and variable soil moisture content (Paredes et al. 2018). Greater decline in biomass production displayed by E. superba compared to E. macrostachyus and C. ciliaris suggests its higher sensitivity to water-deficit conditions. This is because E. superba is found mainly in the relative wetter areas of typical semi-arid grasslands in Africa (Bosch 1989). E. macrostachyus exhibited a higher water-stressed/ well-watered biomass production ratio and a marginal drop in biomass production under water-deficit conditions. This demonstrates that E. macrostachyus is less sensitive to changes in soil moisture content compared to $C$. ciliaris and $E$. superba. Relatively steady biomass production with changes in soil moisture displayed by E. macrostachyus makes it an important species to consider when selecting genotypes for yield and yield stability in African drylands. This is because African dryland soils are truncated and the available soil moisture declines towards the end of the rainy season (Visser et al. 2008).

\section{Conclusions}

Rainwater harvesting has been widely used in diverse social-ecological contexts proving to be a valuable approach to sustainable agricultural production. Diverting runoff from roads into in situ rainwater harvesting structures, e.g., trenches, demonstrated a high potential in enhancing soil moisture availability in a rain-fed native pasture production system in a typical African dryland landscape. Roads provide an additional catchment from which an alternative source of water is harvested. This leads to peaks in the water collection inside the trenches and adds to the in situ rainwater harvesting. Prolonged soil moisture availability increased biomass production of the established grasses, demonstrating the potential to buffer the yield gaps between the rainy seasons, and extends moisture availability at the onset of the dry seasons. There was a decrease in biomass yields with a decline in soil moisture availability as influenced by distance away from the trench. These results show that grass biomass production in African drylands is greatly constrained by soil moisture availability. However, the magnitude of this reduction in yields varied between grass species, signalling differences in sensitivity to water-deficit conditions. Thus, diverting runoff from roads coupled with in situ rainwater harvesting and reseeding using multiple species with contrasting sensitivity to water-stress conditions could be an innovative and strategic approach to increase water productivity, stabilize biomass yields and enhance sustainable native pasture production in African dryland landscapes. Thus, these innovative strategies have a great potential to strengthen the effectiveness of ecological restoration in African drylands to meet the aspirations of the UN Decade 
on Ecosystem Restoration and attaining the UN Sustainable Development Goals.

Acknowledgements The NWO-WOTRO Netherlands Organisation for Scientific Research and Science for Global Development provided financial support for this research project under the Food and Business Applied Research Fund (ARF), 2016. Budget No. 3350, W 08.270.348. Special dedication to our co-author and mentor Prof. Nashon K.R. Musimba who passed on during the implementation of the Rainwater harvesting from roads for indigenous pasture production and improved rural livelihoods in Kenya (ROFIP) research project https://www.nwo. nl/en/projects/w-08270348.

Funding Open Access funding provided by University of Helsinki including Helsinki University Central Hospital.

Data Availability All data generated or analysed during this study are included in this published article and are available from the corresponding author on reasonable request.

\section{Declarations}

Conflict of Interest The authors declare no conflicts of interest.

Open Access This article is licensed under a Creative Commons Attribution 4.0 International License, which permits use, sharing, adaptation, distribution and reproduction in any medium or format, as long as you give appropriate credit to the original author(s) and the source, provide a link to the Creative Commons licence, and indicate if changes were made. The images or other third party material in this article are included in the article's Creative Commons licence, unless indicated otherwise in a credit line to the material. If material is not included in the article's Creative Commons licence and your intended use is not permitted by statutory regulation or exceeds the permitted use, you will need to obtain permission directly from the copyright holder. To view a copy of this licence, visit http://creativecommons.org/licenses/by/4.0/.

\section{References}

Amwata DA, Nyariki DM, Musimba NKR (2016) Factors influencing pastoral and agropastoral household vulnerability to food insecurity in the drylands of Kenya: a case study of Kajiado and Makueni counties. J Int Dev 28:771-787. https://doi.org/10.1002/ jid. 3123

Angassa A (2014) Effects of grazing intensity and bush encroachment on herbaceous species and rangeland condition in southern Ethiopia. Land Degrad Dev 25:438-451. https://doi.org/10.1002/ldr. 2160

Bardgett RD, Bullock JM, Lavorel S et al (2021) Combating global grassland degradation. Nat Rev Earth Environ 2:720-735. https:// doi.org/10.1038/s43017-021-00207-2

Berdugo M, Vidiella B, Solé RV, Maestre FT (2021) Ecological mechanisms underlying aridity thresholds in global drylands. Funct Ecol 00:1-20. https://doi.org/10.1111/1365-2435.13962

Bosch OJH (1989) Degradation of the semi-arid grasslands of southern Africa. J Arid Environ 16:165-175. https://doi.org/10.1016/ S0140-1963(18)31023-1

Broadhurst LM, Lowe A, Coates DJ, Cunningham SA, McDonald M, Vesk PA, Yates C (2008) Seed supply for broadscale restoration: maximizing evolutionary potential. Evol Appl 1:587-597. https:// doi.org/10.1111/j.1752-4571.2008.00045.x
Dass A, Sudhishri S, Lenka NK, Patnaik US (2011) Runoff capture through vegetative barriers and planting methodologies to reduce erosion, and improve soil moisture, fertility and crop productivity in southern Orissa, India. Nutr Cycling Agroecosyst 89:45-57. https://doi.org/10.1007/s10705-010-9375-3

Denison JA, Wotshela L (2012) An overview of indigenous, indigenised and contemporary water harvesting and conservation practices in South Africa. Irrig Drain 61:7-23. https://doi.org/ 10.1002/ird.1689

Derib SD, Assefa T, Berhanu B, Zeleke G (2009) Impacts of microbasin water harvesting structures in improving vegetative cover in degraded hillslope areas of north-east Ethiopia. Rangeland $\mathbf{J}$ 31:259-265. https://doi.org/10.1071/RJ09012

Eriksen S, Lind J (2009) Adaptation as a political process: adjusting to drought and conflict in Kenya's drylands. Environ Manage 43:817-835. https://doi.org/10.1007/s00267-008-9189-0

Erkossa T, Geleti D, Williams TO, Laekemariam F, Haileslassie A (2020) Restoration of grazing land to increase biomass production and improve soil properties in the Blue Nile basin: effects of infiltration trenches and Chloris gayana reseeding. Renew Agric Food Syst. https://doi.org/10.1017/S1742170519000425

Ghannoum O, van Caemmerer S, Conroy JP (2002) The effect of drought on plant water use efficiency of nine NAD-ME and nine NADP-ME Australian C4 grasses. Funct Plant Biol 29:13371348. https://doi.org/10.1071/FP02056

Huang J, Ji M, Xie Y, Wang S, He Y, Ran J (2016) Global semi-arid climate change over last 60 years. Clim Dyn 46:1131-1150. https:// doi.org/10.1007/s00382-015-2636-8

King EG, Unks RR, German L (2018) Constraints and capacities for novel livelihood adaptation: lessons from agricultural adoption in an African dryland pastoralist system. Reg Environ Change 18:1403-1410. https://doi.org/10.1007/s10113-017-1270-x

Koech OK, Kinuthia RN, Karuku GN, Mureithi SM, Wanjogu RK (2016) Irrigation levels affects biomass yields and morphometric characteristics of range grasses in arid rangelands of Kenya. Springer plus 5:1640. https://doi.org/10.1186/s40064-016-3309-8

Lal R (2001) Potential of desertification control to sequester carbon and mitigate the greenhouse effect. Clim Change 51:35-72. https://doi. org/10.1023/A:1017529816140

Lenka NK, Choudhury PR, Sudhishri S, Dass A, Patnaik US (2012) Soil aggregation, carbon build up and root zone soil moisture in degraded sloping lands under selected agroforestry based rehabilitation systems in eastern India. Agric Ecosyst Environ 150:54-62. https://doi.org/10.1016/j.agee.2012.01.003

Marshall VM, Lewis MM, Ostendorf B (2012) Buffel grass (Cenchrus ciliaris) as an invader and threat to biodiversity in arid environments: a review. J Arid Environ 78:1-12. https://doi.org/10.1016/j. jaridenv.2011.11.005

Mganga KZ, Musimba NKR, Nyariki DM, Nyangito MM, Mwang'ombe AW (2015) The choice of grass species to combat desertification in semi-arid rangelands is greatly influenced by their forage value for livestock. Grass Forage Sci 70:161-167. https://doi.org/10.1111/gfs.12089

Mganga KZ, Kaindi E, Ndathi JN, Bosma L, Kioko T, Kadenyi N, Wambua SM, van Steenbergen F, Musimba NKR (2021) Morphoecological characteristics of grasses used to restore degraded semi-arid African rangelands. Ecol Solutions Evid 2:e12078. https://doi.org/10.1002/2688-8319.12078

Mumo L, Yu J, Ayugi B (2019) Evaluation of spatiotemporal variability of rainfall over Kenya from 1979-2017. J Atmos Sol-Terr Phys 194:105097. https://doi.org/10.1016/j.jastp.2019.105097

Mureithi SM, Verdoodt A, Gachene CKK, Njoka JT, Wasonga VO, de Neve S, Meyerhoff E, van Ranst E (2014) Impacts of enclosure management on soil properties and microbial biomass in a restored semi-arid rangeland, Kenya. J Arid Land 6:561-570. https://doi.org/10.1007/s40333-014-0065-x 
Mureithi SM, Verdoodt A, Njoka JT, Gachene CKK, van Ranst E (2016) Benefits derived from rehabilitating a degraded semi-arid rangeland in communal enclosures, Kenya. Land Degrad Dev 27:1853-1862. https://doi.org/10.1002/ldr.2341

Paredes SS, Stritzler NP, Bono A, Distel RA (2018) Perennial warmseason grass monocultures and mixtures: Biomass production and soil improvement in semiarid and shallow soil conditions. J Arid Environ 154:82-88. https://doi.org/10.1016/j.jaridenv.2018.02. 008

Ravhuhali KE, Mlambo V, Beyene TS, Palamuleni LG (2019) A comparative analysis of the morphology and nutritive value of five South African native grass species grown under controlled conditions. Afr J Range Forage Sci 36:67-70. https://doi.org/10.2989/ 10220119.2018.1516236

Ryan C, Elsner P (2016) The potential for sand dams to increase the adaptive capacity of East African drylands to climate change. Reg Environ Change 16:2087-2096. https://doi.org/10.1007/ s10113-016-0938-y

Santos MER, Silveira MCT, Gomes VM, da Fonseca DM, Sousa BML, Santos AD (2013) Pasture height at the beginning of deferment as a determinant of signal grass structure and potential selectivity by cattle. Acta Sci Anim Sci 35:379-385. https://doi.org/10.4025/ actascianimsci.v35i4.20421

Schmitt CB, Kisangau D, Matheka KW (2019) Tree diversity in a human modified riparian forest landscape in semi-arid Kenya. For Ecol Manage 433:645-655. https://doi.org/10.1016/j.foreco. 2018.11.030

Shackelford N, Paterno GB, Winkler DE, Erickson TE, Leger EA, Svejcar LN et al (2021) Drivers of seedling establishment success in dryland restoration efforts. Nat Ecol Evol 5:1283-1290. https:// doi.org/10.1038/s41559-021-01510-3

Sheffield J, Wood EF (2008) Projected changes in drought occurrence under future global warming from multi-model, multi-scenario, IPCC AR4 simulations. Clim Dyn 31:79-105. https://doi.org/10. 1007/s00382-007-0340-z

Sultan D, Tsunekawa A, Haregeweyn N, Adgo E et al (2018) Efficiency of soil and water conservation practices in different agro-ecological environments in the Upper Blue Nile Basin of Ethiopia. J Arid Land 10:249-263. https://doi.org/10.1007/s40333-018-0097-8
Tahir S, Marschner P (2018) Clay addition to sandy soil reduces nutrient leaching-effect of clay concentration and ped size. Commun Soil Sci Plant Anal 48:1813-1821. https://doi.org/10.1080/00103 624.2017.1395454

Tesfahunegn GB, Wortmann CS (2008) Tie-ridge tillage for high altitude pulse production in northern Ethiopia. Agron J 100:447-453. https://doi.org/10.2134/agronj2007.0159

van den Berg L, Kellner K (2005) Restoring degraded patches in a semi-arid rangeland of South Africa. J Arid Environ 61:497-511. https://doi.org/10.1016/j.jaridenv.2004.09.024

Visser M, Reheul D (2001) Restoring depleted Tunisian drylands with native steppic species: where should we source the seeds? Genet Resour Crop Evol 48:567-578. https://doi.org/10.1023/A:10138 64524495

Visser N, Morris C, Hardy MB, Botha JC (2007) Restoring bare patches in the Nama-Karoo of South Africa. Afr J Range Forage Sci 24:87-96. https://doi.org/10.2989/AJRFS.2007.24.2.5.159

Visser M, M'seddi K, Chaïeb M, Neffati M (2008) Assessing yield and yield stability of remnant populations of Cenchrus ciliaris L. in arid Tunisia: developing a blueprint for initiating native seed production. Grass Forage Sci 63:301-313. https://doi.org/10.1111/j. 1365-2494.2008.00642.x

Vohland K, Barry B (2009) A review of in situ rainwater harvesting $(\mathrm{RWH})$ practices modifying landscape functions in African drylands. Agric Ecosyst Environ 131:119-127. https://doi.org/10. 1016/j.agee.2009.01.010

Vundla T, Mutanga O, Sibanda M (2020) Quantifying grass productivity using remotely sensed data: an assessment of grassland restoration benefits. Afr J Range Forage Sci 37:247-256. https://doi.org/ 10.2989/10220119.2019.1697754

Wasonga VO, Ngugi RK, Kitalyi A (2003) Traditional range condition and trend assessment: lessons from Pokot and Il Chamus pastoralists of Kenya. Anthropologist 5:79-87. https://doi.org/10.1080/ 09720073.2003.11890783

Yageta Y, Osbahr H, Morimoto Y, Clark J (2019) Comparing farmers' qualitative evaluation of soil fertility with quantitative soil fertility indicators in Kitui County, Kenya. Geoderma 344:153-163. https://doi.org/10.1016/j.geoderma.2019.01.019 